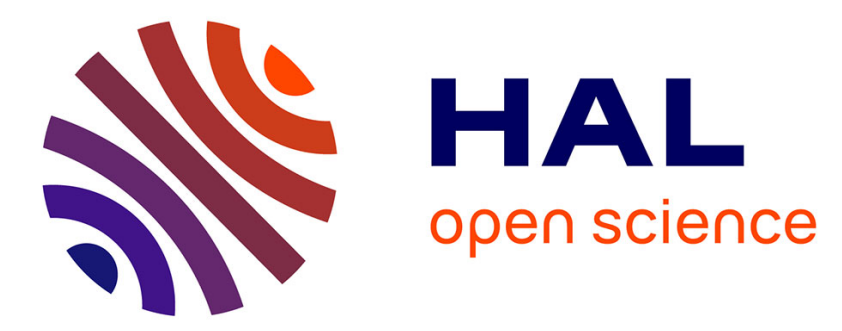

\title{
Is there a pilot in the chain? Identifying the key drivers of change in the fresh pineapple sector
}

\author{
Isabelle Vagneron, Guy Faure, Denis Loeillet, . European Association of \\ Agricultural Economists
}

\section{- To cite this version:}

Isabelle Vagneron, Guy Faure, Denis Loeillet, . European Association of Agricultural Economists. Is there a pilot in the chain? Identifying the key drivers of change in the fresh pineapple sector. 1. International European forum on Innovation and system dynamics in food networks, Feb 2007, Innbsrück-Igls, Austria. 22 p. hal-02821879

\section{HAL Id: hal-02821879 \\ https://hal.inrae.fr/hal-02821879}

Submitted on 6 Jun 2020

HAL is a multi-disciplinary open access archive for the deposit and dissemination of scientific research documents, whether they are published or not. The documents may come from teaching and research institutions in France or abroad, or from public or private research centers.
L'archive ouverte pluridisciplinaire HAL, est destinée au dépôt et à la diffusion de documents scientifiques de niveau recherche, publiés ou non, émanant des établissements d'enseignement et de recherche français ou étrangers, des laboratoires publics ou privés. 


\title{
IS THERE A PILOT IN THE CHAIN? IDENTIFYING THE KEY DRIVERS OF CHANGE IN THE FRESH PINEAPPLE SECTOR
}

\author{
Isabelle VAGNERON, Guy FAURE, Denis LOEILLET
}

CIRAD

\section{INTRODUCTION}

World pineapple production totals nearly 16 million tonnes ${ }^{1} .12$ countries account for $80 \%$ of total pineapple production: six are in Asia (Thailand, Philippines, China, India, Indonesia and Vietnam), four are in Central and South America (Brazil, Costa Rica, Mexico and Colombia) and two in Africa (Nigeria, Kenya). The performance of pineapple makes it a star in the international fruit sector: pineapple production has increased more rapidly than that of fruits in general ${ }^{2}$. Examination of production dynamics over a 45-year period reveals that: (a) total pineapple production has increased four-fold (from 4 to 16 million tonnes); (b) the first 'pineapple crisis' took place in the eraly 1980s, with production falling by $17 \%$ to 8.7 million tonnes; (c) supply resumed growth in 1984, and remained constant until 1993 (12.7 million tonnes); (d) stability dominated until 1998 and was followed by the second break in 1999, when supply increased by 2 million tonnes in a single year (rising by $16 \%$ to 14.4 million tonnes); (e) the annual growth of supply has since been steady and controlled (1-3\% per year); (f) the increase in the quantities available is closely linked to a rise in demand on the major import markets; $(\mathrm{g}$ ) the degree of internationalisation (the import/production ratio) has increased from $16 \%$ in 1960 to $47 \%$ in 2005 . At this stage, it is difficult to go any further without mentioning that there is no such thing as a homogeneous 'pineapple market'. Indeed, this expression fails to distinguish two worlds that have very little in common: that of fresh fruits and that of processed fruits. Three-quarters of the 7.4 million tonnes (fresh fruit equivalent) of pineapples traded in the world are canned pineapples or pineapple juice. In 2005, the fresh pineapple market represented one quarter of the total pineapple market, against one eighth at the beginning of the 1960s.

Processed pineapple: the original engine of growth

With the exception of a slump in the second half of the 1990s, canned pineapple and pineapple juice are responsible for the great dynamism of the market: world trade in processed pineapples has increased fourfold since 1984 (from 1.3 to 5.6 million tonnes, fresh fruit equivalent). In 2004, two thirds of pineapple exports consisted of juice (single or concentrated), the remaining third was canned goods (rings or pieces). The market for processed pineapple is dominated by Asia: the bulk of the processing capacity is located in Thailand, the Philippines, Indonesia and, more recently, Vietnam. Rapid delocation of pineapple production for processing is a permanent feature of the sector. The relative competitiveness of each producing country shapes the world market for processed pineapple. Production in Asia has been relatively stable recently, allowing the market to recover after years of supply volatility. The processed pineapple market is sensitive to production forecasts (especially in Thailand, the leading producer) and to international demand. Supply is very cyclical, due to recurring weather problems (floods/drought) and to the tendency of processors to speculate by twisting information about the quantities available, thus making pineapple purchases by the agroindustry very complex. A new feature of the processed pineapple market (especially juice) is market segmentation: initially centred on the 'Smooth Cayenne' variety, some supplies of 'Sweet' pineapple juice are now available from Costa Rica. This is a direct consequence of the tremendous increase in the quantities of 'Sweet' available on the world market for fresh pineapples.

\section{Effervescence on the fresh pineapple market}

The fresh pineapple market exhibits three main periods: a growth of exports from the second world war to the early 80 s (with a sharp decline of production in the early $80 \mathrm{~s}$ ); from the mid 80 s to the mid $90 \mathrm{~s}$ a steady growth related to improved transportation infrastructure and evolving consumer tastes; from the mid 90s to today, an increase in the volumes traded and the arrival of new producers (Costa Rica, Honduras, Ghana) at the expense of traditional producers such as Côte d'Ivoire. Today, the international

\footnotetext{
${ }^{1}$ Pineapple is the $9^{\text {th }}$ largest fruit crop after pears and before peaches and nectarines.

${ }^{2}$ The index of pineapple production increased from 100 in 1960 to 415 in 2005, against only 291 for fruit.
} 
fresh pineapple market is brisk: pineapple imports have doubled since 1999 in both the USA and Europe 3 . In contrast with the theory of supply and demand, the strong increase in world supply - and hence in pineapple imports - did not result in a price fall. The unit value of fresh pineapples even increased in the USA (the leading import market) from less than USD 400 per tonne in 1994 to a peak of USD 580 in $2002^{4}$. Costa Rica is the great champion of this new era: almost non-existent on the market in the late 80s, it is today a major exporter, and rumor has it that Costa Rican exports of pineapple could reach the million ton in 2006. Recent trends on the world market for fresh pineapple also reflect the fierce battle that takes place between global agro-food giants (Del Monte, Chiquita, Dole, large retailers, to name but some). In this battle, varietal innovation has been a key driver of change - determinating not only who pilots the chain, but also who participates in the market -, so has logistical innovation. More recently, another driver seems to be emerging as firms awaken to the advantages of using private standards as a strategic tool. This shows through the explosion of private and business to business standards aimed at guaranteeing the quality/safety of food products. Varietal, logistical and standard-related innovations play a crucial role in shaping the world pineapple market, but not only. They also determine who will be able to supply - and who will therefore be excluded from the market - in producer countries.

The paper is organized as follows: Section 1 draws on the theoretical framework provided by global value chain analysis to understand the evolution of the fresh pineapple market - leading firm(s), key drivers of change, and the consequences thereof on the operation of the chain. The objective of Section 2 is to capture the historical dynamics of the fresh pineapple market. Three periods are identified, each one characterized by a specific pilot, specific drivers of change and a specific geographical setting that we explicit. Section 3 explores the details of Costa Rica's success story on the pineapple market. We defend the idea that Costa Rica's achievement as a major player on the fresh pineapple market is emblematic of the shifting geographies of production at work in global value chains. Finally, we draw on original data on fresh pineapple production in Costa Rica to explore the deep changes that global markets induce in domestic production structures. Section 4 concludes and discusses the implications of the varietal, technical, logistical and organisational innovations at work on the pineapple market.

\section{GLOBAL VALUE CHAIN ANALYSIS: WHAT'S NEW ?}

The global commodity chain framework was developed in the mid 90s to understand the evolution and the organization of international economic networks. Commodity chains refer to a network of organizations and processes involved in the design, production, and marketing of a finished commodity (Gereffi and Korzeniewicz, 1994; Raikes et al., 2000). Global commodity chains are ussually described along four dimensions: the input-output structure, the geographical coverage, the governance structure and the institutional framework (Gereffi, 1994, 1995).

\section{Governance structure}

The governance structure can be defined as the "authority and power relationships that determine how financial, material and human resources are allocated and flow within a chain" (Gereffi, 1997). More generally, it involves "the ability of one firm to influence or determine the activities of other firms in the chain" (Gereffi et al., 2001). Two types of governance structures are traditionally opposed: (a) buyer-driven chains, where large retailers control the activities of the chain without owning the production facilities and production is usually out-sourced by the key actors who do not actually make the branded products they design and market (apparel, footwear); (b) producer-driven chains, where manufacturers control capitalintensive operations and sub-contract more labor-intensive functions, often through vertical integration (automobile). More recently, Gereffi et al. (2005) refine the typology of forms of governance along a continuum (market, modular, relational, captive and hierarchical). The factors that determine the use of a specific mode of governance include the complexity of transactions, the codifiability of information and the capacities of suppliers. These factors induce transactions costs related to coordination of activities and to asset specificity. This approach is peculiarly relevant in the contemporary food sector, which is organized by large downstream actors (retailers, supermarkets, processors, etc.) who outsource to transnational networks of suppliers. By deciding what is to be produced, when, how and under what conditions, they determine how profits are distributed within the chain and who participates in the

\footnotetext{
${ }^{3}$ In 2005, each one of these areas imported nearly 600,000 tonnes of pineapples.

${ }^{4}$ Imports increased from 131,000 to over 400,000 tonnes over this period.
} 
market $^{5}$, thus shaping the global food system without even owning any production, processing or transportation facilities or producing themselves (Gereffi, 1999). In the horticultural sector, case studies highlight the emergence of tightly structured yet geographically dispersed supply chains controled by supermarkets (Reardon and Berdegué, 2002; Dolan and Humphrey, 1999, 2003). This trend may be explained by a variety of factors including consolidation in the retail sector; the development of direct relations between supermarkets and importers; greater product variety, product innovation, and increasing processing and packaging; traceability of products; change in the regulatory environment; consumer concerns; adoption of new logistics parameters.

Power, standards and leadership

The GCC approach adresses the issue of power in economic relations and transactions. Power is seen not simply as the effect of barriers to entry, but also of organisational changes and of more effective 'supplychain management' implemented by chain leaders. According to Gereffi, power involves the ability to outsource lower value added activities and to retain or incorporate those with higher value-added. Various studies establish a direct relationship between power and standards, based on the observation that most standard-setters are the actors with the highest (market) power (Juska, Gouveia et al., 2000; Bingen \& Siyengo, 2002). The ability to participate in the standard-setting process is strategic, since standards play a significant role in determining who participates in the global food market, and under what conditions (Dolan and Humphrey, 2000; Achterbosch \& Tongeren, 2002). Going one step further, Gibbon \& Ponte mention how the ability of lead firms to diffuse "dominant normative paradigms" provide legitimacy for the mechanisms used to exert "leadership"' (2005:3). Power based on market share is likely to translate into 'vertical power' over suppliers - downward pressure on prices, unilateral changes in contractual relations, changes in buyer-supplier division of labour. The final outcome is increased differentiation between suppliers (differential access to financial resources, economies of scale) and results in the appearance of 'first-tier suppliers' (Gibbon and Ponte, 2006). According to Busch et al. (2005), third party certification reflects and reproduces existing unequal power relations in the global agrifood system. The multiplication of private standards and codes of conduct attests the desire of global buyers to free themselves from - and eventually regain power over - the constraints imposed by the regulatory environment.

In the following section, we explore the evolution of the main features of the fresh pineapples chain using the previous concepts of governance structure, geographical coverage, input-output strcuture and power relations.

\section{IDENTIFYING THE PILOTS AND KEY DRIVERS OF CHANGE ON THE FRESH PINEAPPLE MARKET}

Three main periods can be distinguished, each of which is characterized by a specific pilot, specific drivers of change and a specific geographical setting.

\section{Rise and fall of Côte d'Ivoire}

Côte d'Ivoire dominates the world market for fresh pineapples from the early 60s onwards. The early success of Ivorian pineapple exports can be explained by the country's political stability, the adoption of agriculture-led growth, the proximity to European markets and the limited involvement of the State in production and marketing. The early involvement of Côte d'Ivoire in the pineapple market shows through its role as a standard-setter: Côte d'Ivoire sets up domestic standards for the exports of fresh pineapples as soon as 1971. In the absence of international standards for the international pineapple trade, this standard remains a reference for quite a long time. Things start changing in the mid 1980s: after supplying $74 \%$ of the European market for fresh pineapple in 1976, Côte d'Ivoire's market share falls to $68 \%$ in 1990 due to growing competition from South-East Asia for canned pineapples ${ }^{6}$ and from Central America for fresh pineapples, but not only. In 1985, the parastatal in charge of marketing fruit shuts down followed by the two main processing units in 1988. As a result, exports of transformed pineapples collapse, sending large volumes of pineapples formerly grown to be processed onto the export market. The bulk of the Ivorian pineapple production is subsequently exported to Europe by sea-freight to take adavantage of proximity to Europe. Throughout the 1980s and the 1990s, Côte d'Ivoire is the main hub for shipping fruit by sea

\footnotetext{
5 Their requirements act as effective barriers to entry to participation in the chain by small exporters and farmers, although for those who do participate, the rewards may be substantial.

${ }^{6}$ Thailand expands its exports three-fold, increasing its market share of the canned pineapple market to over $50 \%$.
} 
from West Africa to Europe. In 2001, due to political instability and drought in Côte d'Ivoire, Cameroon (also a major banana exporter) becomes the largest fruit supplier to the European Union.

The winning combination of the 90s: one firm, one country, one product

In the mid 90s, the European market for fresh pineapple has lost its monolithic structure, consisting of one variety ('Smooth Cayenne') and one origin (Côte d'Ivoire). A new variety ('MD-2' or 'Extra Sweet') develops beside traditional supplies, while Costa Rica emerges as a new origin. However, it would be wrong to summarise such success as the result of a simple combination of origin and variety. Indeed, such a reading greatly underestimates the role played by the transnational corporation Del Monte, its logistics and commercial strategy. Del Monte launches the Costa Rican production of the hybrid 'MD-2', rationalises production (several thousand hectares of land in a single holding, an ultra-modern packing station and high-level agricultural support), develops reliable and rapid export logistics, an efficient organisation of sales and a powerful marketing plan. As a result, 'MD-2' enters the high-quality segment and gradually gained market share. Côte d'Ivoire is elbowed out of its own market, Europe, in just a few years by the Costa Rican champion that has also gained a near monopoly of the US market.

The millenium bug? Quality standards and the growing importanceof rge retail sector

In the early 2000s, this model starts running out of steam, while Del Monte's success story seems to be coming to an end. The promising market for the 'MD-2' variety leaves no competitor indifferent: after disputes and court hearings, Del Monte is forced to abandon exclusive rights over the variety, while competitors large and small hurry onto the scene. Dole, Chiquita, Fyffes and other totally unknown operators develop their own supplies, first in Costa Rica, then in Latin America and Africa. The 'Sweet' variety has now become the standard, definitively taking the top spot from the 'Smooth Cayenne'. Meanwhile, public food safety regulations gain importance, while private quality standards promoted by large retailers and agrifood industries play an increasing role in determining access (or denial of access) to international markets.

Pilots and key drivers on the fresh pineapple market

\begin{tabular}{|c|c|c|c|c|}
\hline \multicolumn{2}{|c|}{ end of WWII } & early-mid $80 \mathrm{~s}$ & mid 90s & early 2000 s \\
\hline & Phase 1 & Phase 2 & Phase 3 & $?$ \\
\hline keywords & exports & $\begin{array}{l}\text { logistics, transportation } \\
\text { innovations \& new } \\
\text { consumer preferences }\end{array}$ & $\begin{array}{l}\text { diversity of suppliers, } \\
\text { varieties, standards \& } \\
\text { brands }\end{array}$ & ? \\
\hline pilot (actor) & traders & $\begin{array}{l}\text { large agro-food } \\
\text { companies }\end{array}$ & $\begin{array}{c}\text { large agro-food } \\
\text { companies \& retailers }\end{array}$ & ? \\
\hline pilot (country) & Côte d'Ivoire & Costa Rica & Costa Rica + others & ? \\
\hline drivers of governance & market access & market share & risk management & $?$ \\
\hline tools of governance & fret & varietal innovation & standards \& brands & ? \\
\hline attributes & search & experience & credence & ? \\
\hline variety & Smooth Cayenne & MD-2 & MD-2 & ? \\
\hline
\end{tabular}

\section{QUALITY STANDARDS, VARIETAL INNOVATIONS AND POWER RELATIONS WITHIN THE VALUE CHAIN: THE CASE OF COSTA RICA}

\section{Pineapple production in Costa Rica}

Huetar Norte is Costa Rica's main pineapple production region, totalling almost $50 \%$ of the total pineapple planted area. Most small farmers are located in this region: $95 \%$ of the farmers cultivate less than 10 ha, representing $15 \%$ of the cultivated area. Currently the 'MD-2' variety dominates the market and represents $95 \%$ of the cultivated area, with most of the production dedicated to fresh pineapple exports. However, small farmers mainly plant older varieties and sell mainly (but not exclusively) to the national food industry and to the national fresh product market. As a consequence, only a small part of their production is exported. Most business opportunities are tied to the fresh export market towards the USA (55\%) and Europe (45\%). 
On international markets, producers face increasingly strict standards related to consumer demands expressed through national regulations and private standards. Three main sets of standards dominate the pineapple activity: in Europe, maximum residue limits (MRLs) define the maximum amount of residues that can be found in fresh agricultural products, while EurepGap is a private standard requested by a growing number of European supermarkets; in the USA, the Bioterrorist Act enacted in 2005 requires the implementation of a traceability system and the registration of the exporters. All of theses standards are extremely difficult to comply with for small farmers. Compliance with these standards generates strong changes both at the farm and at the supply chain level.

\section{Barriers to entry at the farm level}

Most standards ask for the compliance with national labor $^{7}$ and environmental regulations, namely by requiring a strict management of inputs to limit the contamination of harvested products and the environment. Technical changes are thus needed to respect the national regulations on pesticide use, while specific private standards may require extra ajustment: the EurepGap certification requires that farmers use potable water for chemical treatments and carry out specific agricultural practices to preserve natural resources. As a result, standards often require a high level of investment in productive infrastructures ${ }^{8}$ (storage facilities, access to potable water, warehouse for pesticides, toilets for workers, etc.). Such investment costs add to the initial and recurring certification costs. The annual certification costs range between 700 and 1,000 US $\$$ per farm and represent 1-4\% of the gross margin for large farms (5-100 ha) and $25-60 \%$ of the gross margin for small farms (0.5-1.0 ha). Finally, farmers often lack the basic skills (e.g. reading and writing) that would enable them to properly implement traceability systems based on book keeping (EurepGap and BioTerrorism Act). This calls for the intervention of a technician when farmers are not able to manage it properly. Public institutions provide information and training sessions to help small farmers access EurepGap certification through farmers organizations. However, since only $50 \%$ of the farmers are involved in a farmer organization, many farmers lack adequate information and training and are therefore excluded from highly remunerative markets.

At the supply chain level, the emergence of large-scale players

Transnational and national capitalistic firms that produce and export most of the fresh pineapple do not experience any difficulties in implementing the new standards. Their agricultural practices are standardized, specific investments have been made, and the farms are managed by highly qualified labour. To compete on international markets they have already acquired other certifications such as ISO 9002, ISO 14001 or HACCP.

Small scale farmers and medium scale farmers do not export fresh pineapples directly, but rather sell to producing and exporting firms. These firms buy additional product to supply their customers. To reduce transaction costs and to improve their control over the quality of the products, large firms select a small number of EurepGap-certified suppliers that they help through loans or co-investments. The same process happens in farmer organizations: some farmers are selected according to their ability to meet market requirements, while the bulk of the farmers produce for the national market for fresh pineapples or for the agro-industry. A survey of farmer organizations shows that only $50 \%$ of their members are able to comply with EurepGap and to finance the whole process, provided they obtain some assistance from a public institution. However, new transportation and packing rules prohibiting the mix of harvests from different origins contribute to further weaken the smallest farmers.

Finally, the need for traceability and for increased control over the quality of the products generates important changes at the supply chain level: (1) most of the small packing firms do not meet national or international standards, cannot finance the changes requested and thus will be removed and replaced by larger packing firms; (2) larger firms usually produce pineapples and select a few efficient middle-size pineapple producers (5-50 ha), thus contributing to the rapid elimination of a large number of small alternative suppliers; (3) the supply chain is progressively dominated by large producing-packing-exporting firms and by large packing-exporting units.

\footnotetext{
${ }^{7}$ This is difficult for farmers who hire undeclared and migrant paid workers for the most difficult tasks.

${ }^{8}$ Investment for EurepGap certification totals 2,000-2,500 US\$ for small farms (1-5 ha).
} 